\title{
Computer Self-Efficacy and Organizational Culture In Affecting Technology Acceptance Model
}

\author{
Ulfah Mediaty Arief, Sri Sukamta, TatyantoroAndrasto, Subiyanto, FitriaEkarini, Agung Adi \\ Firdaus, AchmadRifaldi, Radiva Hera Oktiagi
}

email : ulfahmediatyarief@mail.unnes.ac.id

${ }^{1}$ Universitas Negeri Semarang

Article History: Received: 11 January 2021; Accepted: 27 February 2021; Published online: 5 April 2021

\begin{abstract}
As the leading provider of education, teachers need to have high technology adoption skills. There is LMS technology in inputs that can streamline learning practices. Mostly with inclusion of the impact of organizational culture and machine self-efficacy on LMS Schoology, this study aims to see the capacity of technology acceptance by teachers using the Technology Acceptance Model (TAM).The results of the study using the model described above for teachers in the cities of Salatiga and Boyolali show that organizational culture does not have a major impact on attitude or purpose to use towards LMS Schoology.The self-efficacy of computers may not affect perceived utility, but has a substantial impact on perceived ease of use. The model also indicates that teachers, while they find it difficult to incorporate it, have a positive attitude towards the nature of LMS technology.
\end{abstract}

Keyword: Computer Self-Efficacy, Organizational Culture, Technology Acceptance Model

\section{INTRODUCTION}

In promoting learning programs, teachers are at the forefront of integrating the use of information technology. To day, the advancement of information and communication technology has created an excellent opportunity for teacher $\mathrm{s}$ and students, through online learning, to experience teaching and learning experiences beyond their conventional $\mathrm{cl}$ assrooms.Learning experiences that are constrained at this time without being in the classroom make it necessary for teachers to be able to take advantage of the information technologies available to address different challenges. The ve ry rapid advancement of technology nowadays means that different practices, including in the field of teaching and le arning activities, can be carried out rapidly and effectively

In online learning activities, there are many words used, including e-learning and LMS. Online learning (elearning) is the use of the Internet as a technical tool that enables users to engage with information, with other users, and to obtain help during the learning process so that they can gain knowledge, construct personal value, and experience learning (Ally, 2006).In addition, a learning management system (LMS) is defined as an online learning platform for the organization and management of learning (Anderson, 2008; Paulsen, 2003). More precisely, LMS is described as a hierarchical architecture that regulates the entire organization's learning process (Watson \& Watson, 2007).LMS has three fundamental characteristics, namely the creation of classes (creation of modules, learning materials and group work), tools for students and tutors (access to learning materials, contact between teachers and students and students) and administrative processes (registration, registration of classes and grouping of students) (Paulsen, 2003).

There are several factors that cause an instructor to use an LMS to conduct online learning activities. In this research, the Technology Acceptance Model (TAM) is used to evaluate the variables that affect a technology that can be embraced and used in learning activities by an instructor.The self-confidence of a teacher about his or her ability to execute a task using information technology devices has an effect on the teacher's understanding of the ease of mastering information technology and the benefits of enhancing performance using information technology.Organizational culture is an integral part of shaping the mindset and choices of a teacher in the application of technology in learning activities.

The purpose of this study is to evaluate the variables influencing the intention to use LMS in learning using the model of technology acceptance (TAM) that is influenced by organizational culture and self-efficacy of the machine.This study may contribute to our theoretical understanding of variables that affect teacher output from the side of organizational culture and machine self-efficacy using modern technology in their teaching activities. 2.

\section{LITERATURE REVIEW}

The Technology Acceptance Model (TAM) is a model developed by Davis (1989) to analyze technology adoption intentions. The relationship between perceived utility (PU), perceived ease of use (PEU), usage attitudes (Attitude / AT), and behavioral purpose (BI) to use technology is defined by TAM. It has been reported among these 
variables that BI mainly attributed to actual use (Davis, 1989), and its been frequently used as an outcome variable (Teo, Huang, \& Hoi, 2017). In TAM, PU refers to the way a person believes that his job performance will be enhanced by using technology. The PEU, which is described as the degree to which a person believes that using technology will be free of effort, can predict this (Davis 1989). PU and PEU have a major impact on individual AT, which is characterized as the degree to which users like the use of technology or dislike it. The individual IU is influenced directly by AT and PU. A technology adoption model (TAM) will be designed and assembled to assess the intentions of teachers to use technology in teaching activities.

Huang \& Teo (2020), by looking at perceptions of organizational culture and school policies, conducted research on technology acceptance among teachers in China. This study aims to explore the effect of the organizational culture point of view and also to see the effects of school policies on the use of technology on teachers' acceptance of information technology. This article expands a Davis (1989) tech innovation model (TAM) by applying organizational culture and school policy variables.

Organizational culture is a method the members of an organization use or adhere to (Robbins \& Judge, 2007). Organizations with a good organizational culture establish the ideals and standards that apply as criteria and are adhered to by each member of the organization (Robbins \& Judge, 2007). Organizational culture is now a trait of an organization in carrying out activities in order to achieve mutually agreed organizational objectives (Hariani, Mujilan, \&Purbandari, 2013; Sugiartini\&Dharmadiaksa, 2016). Organizational culture in school refers to the way people perceive, think, and feel about school and its related components (Zhu, Devos, \& Li, 2011). There's many types of organizational culture, like goal orientation, creativity orientation, leadership, participatory decision-making, mutual vision, and structured relationships (Zhu 2015). OC frames the expectations and decision-making of teachers as a holistic body in the adoption of technology. However, its function has not been thoroughly investigated previously (Zhu, 2015).

Computer Self Efficacy is the confidence we have in use of devices (Bandura, 1994). One of the variables that significantly affects people in their decision to use computer technology is self-confidence. In several studies, machine self-efficacy has been seen as a vector affecting PEU and PU (Grandon, Alshare, \& Kwun, 2005). It is hypothesized to have a positive relationship with PU and PEU, provided that machine self-efficacy conveys ideas about the ability of teachers to use technology in learning activities.

\section{PROPOSED MODEL}

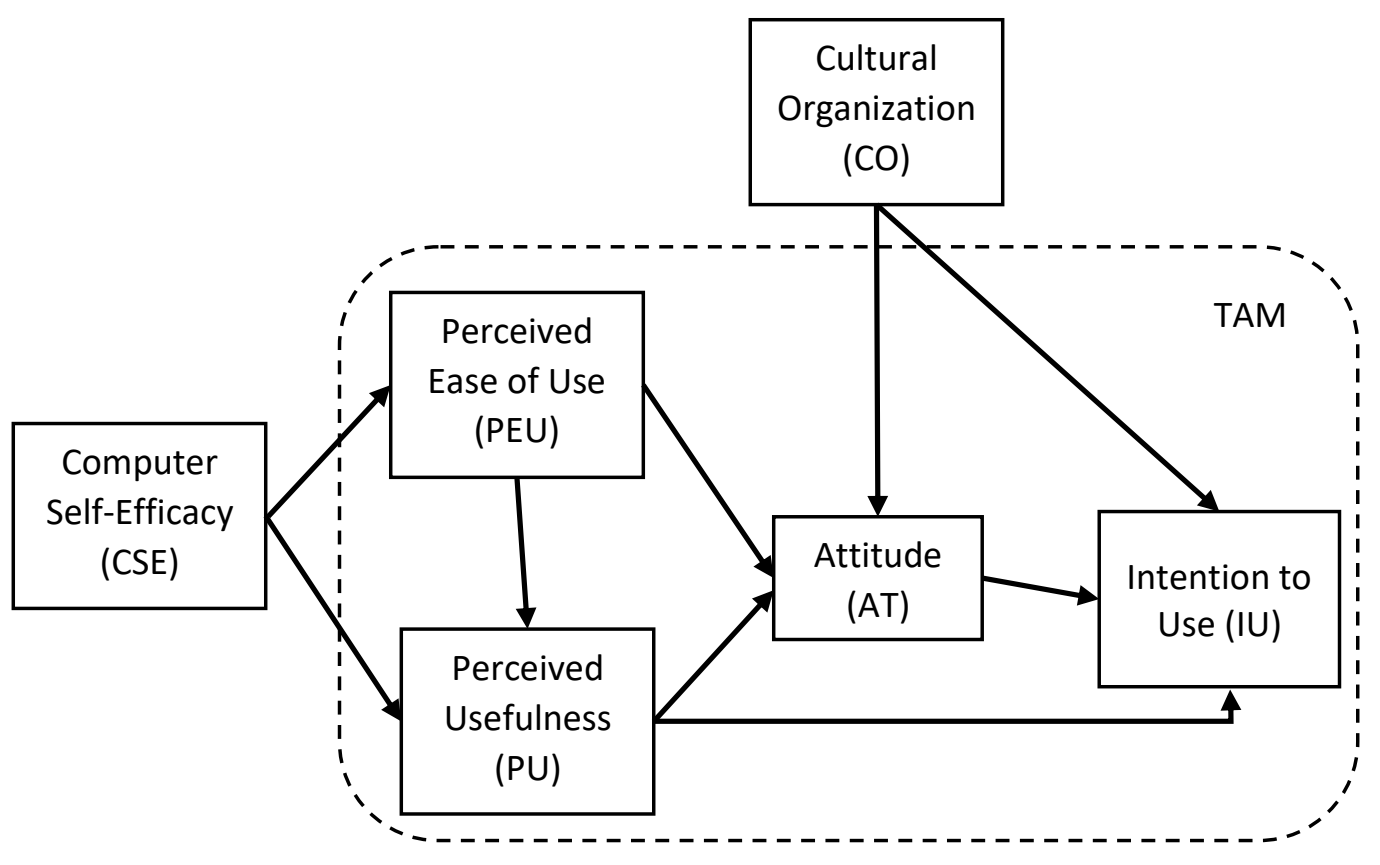

Figure 1 Proposed extended TAM model

Technology Acceptance Model (TAM)

Based on the above literature analysis, the factors that decide the intention to use are attitude (AT) and perceived usefulness (PU) (IU). The direct effect of PU and perceived ease of use (PEU) on AT is direct and PEU has a direct influence on PU. 
Ulfah Mediaty Arief, Sri Sukamta, TatyantoroAndrasto, Subiyanto, FitriaEkarini, Agung Adi Firdaus, AchmadRifaldi, Radiva Hera Oktiagi

H1: PU has a significant effect on AT

H2: PU has a significant effect on IU

H3: PEU has a significant effect on PU

H4: PEU has a significant effect on AT

H5: AT has a significant effect on IU

Cultural Organization (CO)

OC frames the attitudes of teachers and their embrace of technology decision making. OC has an effect on mood (AT) and also on a technology's intention to use (IU).

H6: CO has a significant effect on AT

H7: CO has a significant effect on IU

Computer Self-Efficacy

One of the others that harms people in their decision to use computer technology is self-confidence. CSE has an effect on the perceived utility (PU) and perceived ease (PEU) of technology use of an instructor.

H8: CSE has a significant effect on PU

H9: CSE has a significant effect on PEU

\section{METHOD}

In order to collect data from the respondents, this study used a survey approach using a 7-point Likert scale questionnaire. These parameters are processed using the program WarpPLS that uses the model PLSSEM. PLSSEM is a technique for testing with little data the association between the proposed constructs.

Teachers in the city of Salatiga and Boyolali district were respondents in this study and 78 respondents were interested as a study sample. 27 (34.6 percent) respondents were male, and 51 (65.4 percent) respondents were female, based on the data in the table below. Teachers with an age range of 40 years were the majority of respondents in this report.

Table 1 Demographic data

\begin{tabular}{llll}
\hline Demographics & Category & Frequency & Presentage \% \\
\hline Gender & Male & 27 & 34.6 \\
& Female & 51 & 65.4 \\
\hline Age & $20-25$ & 2 & 2.6 \\
& $26-30$ & 14 & 17.9 \\
& $31-35$ & 6 & 7.7 \\
& $36-40$ & 5 & 6.4 \\
& $41-45$ & 15 & 19.2 \\
& $46-50$ & 7 & 9.0 \\
& $51-55$ & 18 & 23.1 \\
& $>55$ & 11 & 14.1 \\
\hline
\end{tabular}

\section{RESULT AND DISCUSSION}

Construct Reliability and Convergent Validity

The association between constructs and latent variables is calculated by convergent validity. It can be seen in the loading factor in determining the convergent validity of verifying the reliability for retail companies. The magnitude of the correlation between each measurement item (indicator) and its construction is defined by the loading factor. The loading factor value $>0.7$ is said to be ideal, implying that in measuring the build, the indicator is said to be valid. A loading factor value $>0.5$ is still appropriate in the experience of scientific study. Loading factor values $<0.5$ should therefore be omitted from the model.

The next step we see, after evaluating the loading factor value, is the reliability accuracy of the Alpha and Composite Reliability (CR) values of the Cronbach.In calculating internal consistency, composite reliability (CR) is better than Cronbach's Alpha in SEM because CR does not expect the same boot from every predictor. Compared to Composite Reliability, Cronbach's Alpha appears to underestimate build reliability (CR).

The interpretation of Composite Reliability (CR) is the same as Cronbach's Alpha. It is appropriate to have a limit value> 0.7, and a value> 0.8 is quite satisfactory. The Average Occurred (AVE) value is another metric of convergent validity. The AVE value defines the quantity of variance or set of manifest variables that latent constructs may have. Therefore, the greater the variation or spectrum of manifest variables that the latent partners can include, the greater the representation of the manifested variable to its latent constructs. 
For the parameters in the evaluation of convergent validity, use of AVE is recommended. A minimum AVE value of 0.5 implies that convergent validity is a reasonable indicator. That is, an average of more than half the variance of the predictor can be explained by the latent variable. The value of the AVE is derived from the number of loading factor squares separated by the error.

The composite reliability and Cronbach alpha value shown in Table 2 as a whole indicate that a value greater than 0.70. is provided by each latent variable The resulting AVE value shows results above 0.5 for any latent variable. These findings show that both of these factors have a high degree of reliability.

Discriminant Validity

Using AVE's square root value on the association between constructs, the discriminant validity of the reflective model was assessed. The root AVE value must be higher than the correlation between constructs and other constructs, or the AVE value must be higher than the square correlation between constructs, another indicator of discriminant validity.

Based on the results shown in the table, it can be shown that the relationship of the AVE root square between the variables shows that the latent variable's AVE root square value for oneself is greater than the other latent variables. It can be inferred from the shown results that the discriminant validity is appropriate.

Table 2 Construct reliability and Convergence validity

\begin{tabular}{|c|c|c|c|c|c|}
\hline Construct & Item & $\begin{array}{l}\text { Loading } \\
\text { Factor }\end{array}$ & $\begin{array}{l}\text { Composite } \\
\text { Reliability } \\
\end{array}$ & AVE & $\begin{array}{l}\text { Cronbach's } \\
\text { Alpha }\end{array}$ \\
\hline Computer & CSE1 & 0.961 & 0.979 & 0.939 & 0.968 \\
\hline \multirow[t]{2}{*}{ Self Efficacy } & CSE2 & 0.976 & & & \\
\hline & CSE3 & 0.970 & & & \\
\hline Cultural & $\mathrm{CO} 1$ & 0.785 & 0.913 & 0.677 & 0.880 \\
\hline \multirow[t]{4}{*}{ Organization } & $\mathrm{CO} 2$ & 0.827 & & & \\
\hline & $\mathrm{CO} 3$ & 0.845 & & & \\
\hline & $\mathrm{CO} 4$ & 0.861 & & & \\
\hline & $\mathrm{CO} 5$ & 0.793 & & & \\
\hline Perceived & PU1 & 0.918 & 0.950 & 0.825 & 0.929 \\
\hline \multirow[t]{3}{*}{ Usefulness } & PU2 & 0.925 & & & \\
\hline & PU3 & 0.900 & & & \\
\hline & PU4 & 0.890 & & & \\
\hline Perceived & PEU1 & 0.919 & 0.965 & 0.872 & 0.951 \\
\hline \multirow[t]{3}{*}{ Ease of Use } & PEU2 & 0.945 & & & \\
\hline & PEU3 & 0.934 & & & \\
\hline & PEU4 & 0.937 & & & \\
\hline \multirow[t]{3}{*}{ Attitude } & AT1 & 0.862 & 0.903 & 0.757 & 0.839 \\
\hline & AT2 & 0.903 & & & \\
\hline & AT3 & 0.843 & & & \\
\hline Intention to & IU1 & 0.890 & 0.941 & 0.726 & 0.921 \\
\hline \multirow[t]{4}{*}{ Use } & IU2 & 0.904 & & & \\
\hline & IU3 & 0.875 & & & \\
\hline & IU4 & 0.826 & & & \\
\hline & IU5 & 0.866 & & & \\
\hline
\end{tabular}

Table 3 Discriminant validity

\begin{tabular}{|c|c|c|c|c|c|c|}
\hline Construct & CSE & $\mathrm{CO}$ & PU & PEU & AT & IU \\
\hline $\begin{array}{l}\text { Computer Self } \\
\text { Efficacy }\end{array}$ & 0.969 & & & & & \\
\hline $\begin{array}{c}\text { Cultural } \\
\text { Organization }\end{array}$ & 0.464 & 0.832 & & & & \\
\hline $\begin{array}{l}\text { Perceived } \\
\text { Usefulness }\end{array}$ & 0.593 & 0.493 & 0.908 & & & \\
\hline $\begin{array}{l}\text { Perceived Ease of } \\
\text { Use }\end{array}$ & 0.832 & 0.412 & 0.736 & 0.934 & & \\
\hline Attitude & 0.542 & 0.503 & 0.832 & 0.651 & 0.870 & \\
\hline
\end{tabular}


Ulfah Mediaty Arief, Sri Sukamta, TatyantoroAndrasto, Subiyanto, FitriaEkarini, Agung Adi Firdaus, AchmadRifaldi, Radiva Hera Oktiagi

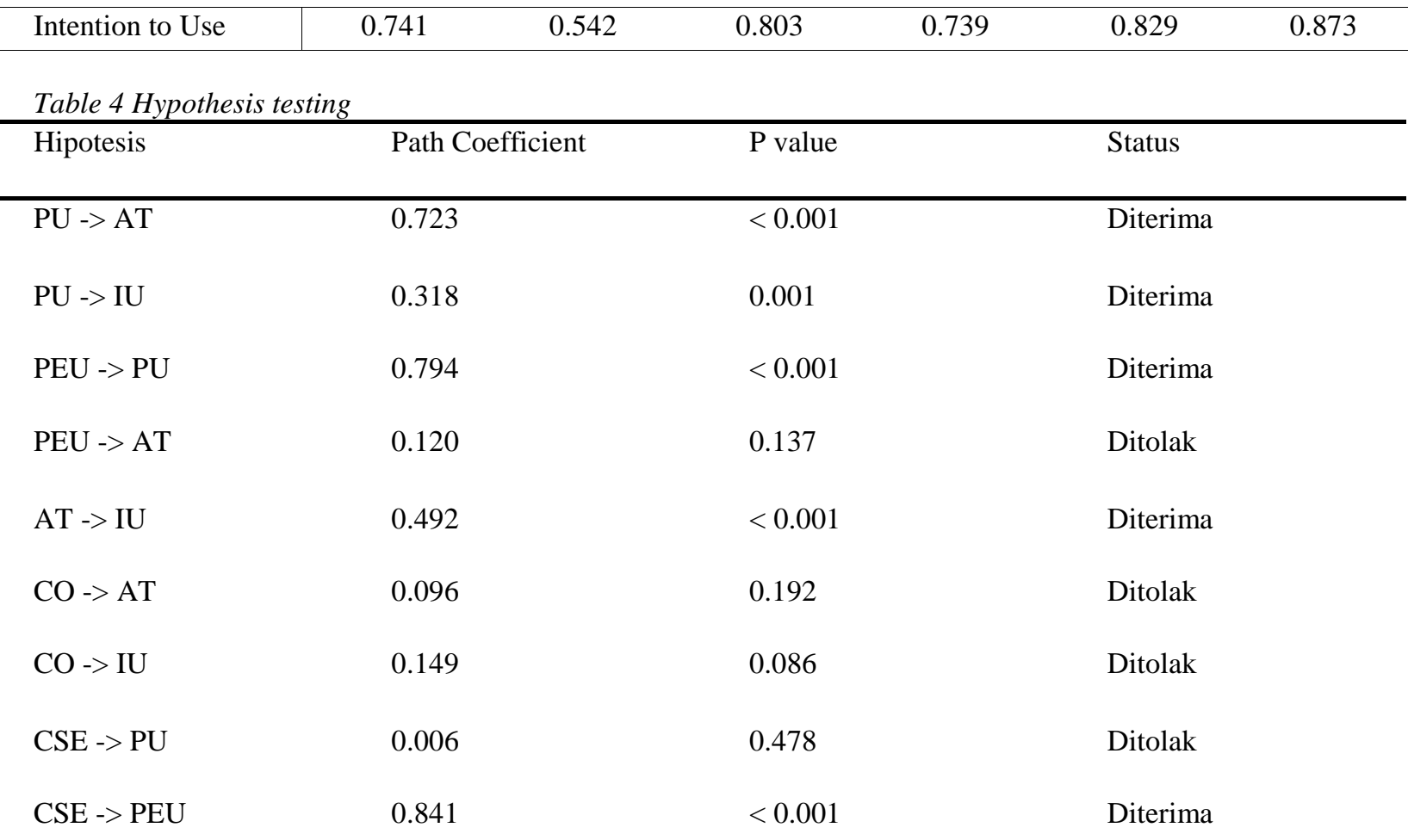

There is no major effect of organizational culture on the mindset or purpose to use towards LMS Schoology. This may be due to the lack of attention and support provided to the environment of the organization for the use of information technology, especially LMS. The self-efficacy of computers does not affect perceived utility, but has a substantial impact on perceived ease of use. This suggests that trust in computers only affects the view that the LMS is easy to use, but not the view that the LMS is useful or helpful. The perceived ease of use of the LMS does not influence attitudes towards the LMS technology. This can be attributed to the number of respondents over 40 years of age who find modern technologies challenging to understand. However, even though they find it hard to incorporate it, they have a positive attitude towards the life of LMS technology. A greater number of respondents are required to use future research and even consider age and teaching experience.

\section{Reference}

1. Ally, M. (2006). Foundations of Educational Theory for Online Learning *. Foundations of Educational Theory For Online Learning, 1(2), 111-136.

2. Bandura, A. (1994). Self-Efficacy. Encyclopedia of Human Behavior, 4(1994), 71-81. https://doi.org/10.1002/9780470479216.corpsy0836

3. Davis, F. D. (1989). Perceived Usefulness, Perceived Ease of Use, and User Acceptance of Information Technology. Mis Quarterly, 13(3), 319-340. https://doi.org/10.2307/249008

4. Hariani, D., Mujilan, \& Purbandari, T. (2013). Dukungan Manajerial dan Budaya Organisasi untuk Menuju Efektivitas Sistem Informasi. Jurnal Riset Manajemen Dan Akuntansi, 01(02), 29-36.

5. Huang, F., \& Teo, T. (2020). Influence of teacher - perceived organisational culture and school policy on Chinese teachers ' intention to use technology: an extension of technology acceptance model. Educational Technology Research and Development, 68(3), 1547-1567. https://doi.org/10.1007/s11423-019-09722-y

6. Paulsen, M. F. (2003). Experiences with Learning Management Systems in 113 European Institutions. Educational Technology \& Society, 6(4), 134-148.

7. Robbins, S. P., \& Judge, T. A. (2007). Organizational Behaviour (2nd ed.).

8. Sugiartini, N. M., \& Dharmadiaksa, I. B. (2016). Pengaruh Efektivitas Teknologi Sistem Informasi Akuntansi Pada Kinerja Individu Dengan Budaya Organisasi Sebagai Pemoderasi. E-Jurnal Akuntansi Universitas Udayana, 14(3), 1-28.

9. Teo, T., Huang, F., \& Hoi, C. K. W. (2017). Explicating the influences that explain intention to use technology among English teachers in China. Interactive Learning Environments. 
Computer Self-Efficacy and Organizational Culture In Affecting Technology Acceptance Model

https://doi.org/10.1080/10494820.2017.1341940

10. Watson, W. R., \& Watson, S. L. (2007). An Argument for Clarity: What are Learning Management Systems, What are They Not, and What Should They Become ? TechTrends, 51(2), 28-34.

11. Zhu, C. (2015). Organisational culture and technology-enhanced innovation in higher education. Technology, Pedagogy and Education, 24(1). https://doi.org/10.1080/1475939X.2013.822414

12. Zhu, C., Devos, G., \& Li, Y. (2011). Teacher perceptions of school culture and their organizational commitment and well-being in a Chinese school. (12). https://doi.org/10.1007/s12564-011-9146-0 